\title{
支部総会
}

\section{第17回 日本ウイルス学会北海道支部夏季シンポジウム}

\author{
日 時：昭和 58 年 7 月 30,31 日（土・日） \\ 会 場：支䇖湖畔国民休睱村
}

\section{「レトロウイルスの現状」プログラム}

7 月30日（土） $14: 30 \sim 17: 00$

1. 成人 $\mathrm{T}$ 細胞白血病ウイルスの感染と血清疫学: non-endemic な北海道を中心に

$$
\begin{array}{ccc}
(14: 30 \sim 15: 30) & \text { （座長 } & \text { 里 外誉郎 博士） } \\
\text { 北大・癌研・ウイルス } & \text { 岩 永 未知代 } \\
& \text { 藤 原 成 悦 } \\
(15: 30 \sim 15: 40) & &
\end{array}
$$$$
\text { 休想 }
$$

2. レトロウイルスの発癌遺伝子と腫瘍特異抗原
$(15: 40 \sim 16: 40)$ (座長 大 里 外誉郎 博士) 北大·癌研・遺伝 葛 巻暹
総 合 討 論
(16: 40 17:00)
（座長 大 里 外誉郎 博士）
懇 親 会
(18:00 20:00)

7 月31日（日）

1. C 型レトロウイルスと自己免疫疾患

(9:30 12:00)

$(9: 30 \sim 10: 30)$

（座長 葛 巻

暹 博士） 札幌市立病院・病理 吉 木敬

休 㮩 $(10: 30 \sim 10: 40)$

2. 牛白血病ウイルス (BLV) による牛リンパ肉腫の形成

$(10: 40 \sim 11: 40)$ (座長 見上龙 博士) 北大・獣医・伝染病 小 沼操 総 合 討 論 (11:40 12:00, 座長 葛 巻暹 博士・見上赽 博士 $)$

1. 成人 $\mathbf{T}$ 細胞白血病ウイルスの感染と血清疫学 : non-endemic な北海道を中心に

北大・癌研・ウイルス 岩永未知代, 藤原 成悦

成人 $\mathrm{T}$ 細胞白血病 (Adult $\mathrm{T}$ cell leukemia, ATL) は西南日本を endemic area とする予後不良の末梢 $\mathrm{T}$ 細 胞型白血病で, 肝脾腫, 皮瑭浸潤などを高頻度に併発し, その白血病細胞は核の分葉を示すのが特徵である.

ATL 培養細胞株 MT-1 の IUdR 処理により ATL 関連抗原 ATLA が誘導され C 型レトロウイルス (ATLV) が見出される.ATLA A ATLVに関連する 抗原と考えられるが, MT-1 を標的として ATL 患者血 清による蛍光抗体間接法を行うと, ほぼ100\%に ATLA 抗体が検出され, endemic area においては中高年健康 人の本抗体陽性率が $20 \%$ 及ぶことが知られている。

当教室では non-endemic 北海道でのATL と
ATLV の因果関係を，患者拈よびその家族を中心に解 析をすすめている.

1）北海道出生 ATL（77年10月～83年 5 月） 23 例の 全てが ATLA 抗体陽性 (100\%) であるのに対し, 一 般住民の陽性率は20/2, 122 (0.9\%) と低值であった.

2）上記 ATL の 9 例中, 健康者家族 54 人を調查した 結果 25 人 (46\%) が ATLA 抗体陽性であった. その内 訳は患者配偶者で71\%, 兄弟 $57 \%$, 子供 $42 \%$ な゙゙が高率 であり, 侽・姪・配偶者の兄弟では $11 \%$ であった。

3）一般住民の抗体陽性例中, 追跡し得た14例におい ては, endemic area の出身者は㫮無で, 9 例 (64\%) に輸血の既往があり, 2 例（うち輸血歴 1 例）の家族 7 人の検索で抗体陽性者は見られなかった (0\%).

以上より ATLV 浸淫度の低い北海道に扔いて, ATL 患者家族に抢ける高率の本ウイルス感染の可能性が示さ れた. 感染経路としては夫婦間および母子間の家族内伝 
播, 及び一般住民においては輸血の存在が考えられた。

\section{2. レトロウイルスの発癌遺伝子と腫瘍特異抗原}

\section{北大 $\cdot$ 癌研 $\cdot$ 遺伝 葛巻 暹}

マウスなど実験動物の腫瘍では, 腫瘍の拒絶に重要な 役割を果す腫瘍特異的細胞表面抗原（TSSA）の存在が， 種々の免投学的手法により確認されてきた. しかし，乙 の抗原の発現を支配している遺伝子についての研究は少 なく, またヒトの癌に TSSA が存在するという確実な 証拠むまだ得られていない，近年レトロウイルス関連の 発癌遺伝子の研究の進展により, 腫瘍特異抗原を発癌遺 伝子産物としてとらえることが可能になった.ささらに発 癌遺伝子はヒトの細胞にも存在することから, 発癌遺伝 子と腫瘍特異抗原の関連性を探ることは, 人癌の腫瘍特 異抗原を検索するためのアプローチとして有効な方法で あると考えられる。

我々はラウス肉腫ウイルス (RSV) によって誘発され たマウス及びラット腫瘍を用いて, てれらの腫演に発現 する TSSA と, RSV が持つ遺伝子の関連性について 検討した. その結果 RSV 誘発腫瘍に共通の TSSA の 発現は RSV の env 遺伝子の発現とは無関係であり, RSV の発癌遺伝子である src 遺伝子の発現と平行する という成績を得た.

次にある一つの RSV マウス腫瘍 (CSAIM) には, この共通の TSSA とは別に, 化学発癌剂誘発腫瘍に見 られるような, その腫瘍に固有の TSSA が存在するて とがモノクロナル抗体を用いて確かめられた.

そこでてれらのラウス腫瘍に共通の TSSA と CSAIM に固有の TSSA が互いに連鎖している遺伝形質か否か を体細胞遺伝学の手法を用いて検討したところ, 固有 TSSA のみを発現し, 共通TSSA を発現しない雑種ク ローンを得るととができた．乙のととは 2 つの形質は独 立したあのであり, 固有 TSSA の発現に関与する遺伝 子は src とは異なる遺伝子であると考えられた.

以上の成績は, レトロウイルスによって誘発される腫 瘍においては, レトロウイルスの発癌遺伝子によって支 配される TSSA と, レトロウイルス感染によって活性 化される細胞性遺伝子によって支配される TSSA があ るととを示唆している。

\section{3. $\mathrm{C}$ 型レトロウイルスと自己免疫疾患}

札幌市立病院 - 病理 吉木 敬

SLE をはじめとするヒトの 自己免疫病がウイルスの 感染を基盤として発生するのではないかという仮説の前
提には, ウイルス感染によって一過性に種々の自己抗体 の出現をみることや，自己免疫病変が誘発されるという 事実がある、C型レトロウイルスは主としてリンパ性悪 性腫瘍に括ける病因的役割について精力的な研究が展開 されてきたが, 近年マウスのC型レトロウイルスが自己 免疫病の病因として重要な役割をあつてとが明らかにさ れてきた. 一般にウイルス感染による自己免疫病の発生 機序はウイルス感染による自己抗原の修飾, ウイルス感 染がもたらす直接的または間接的なリンパ系細胞の障害 による免疫系の失調, B 細胞系の多クローン性活性化, 禁止クローンの活性化等で説明されている. 自己抗体産 生や自己免疫病変が持続性進行性となるためにはウイル スが持続感染性性格をもつことや，宿主がウイルスやウ イルス支配抗原に対して免疫応答性を示すととが必要な 条件と考えられる．乙の様な条件が一度にそろうことは 難しいことのように思われるが，ヒト SLE の自然発生 モデルである New Zealand マウスやヒト PN に酷似 する壊死性動脈炎を自然発生する $\mathrm{SL} / \mathrm{Ni}$ マウスではこ れらマウス系に潜在感染するC 型レトロウイルスと宿主 との間にはこれに近い条件が成立していることが次第に 明らかとなっている，乙てでは，乙れらマウス系に自然 発生する自己免疫病に病因論的に関与する C型レトロウ イルスの役割について述べ，更にヒト SLEをはじめと する自己免疫疾患に扫けるC型レトロウイルスの病因論 的役割の可能性を指摘したい.

\section{4. 牛白血病ウイルス $(\mathrm{BLV})$ による牛リンパ肉腫 の形成}

北大・獣医・伝染病 小沼 操

BLV 感染から発病までの期間はきわめて長い（1 年 〜数年). この理由について生体の側とウイルスの側か ら検討している.

I. 生体の側からの検討 (Immunosurveillance)

羊に $\mathrm{BLV}$ 材料を接種し， 3 年以上にわたり液性免疫 (gp 51， p 24 および BLV-transformed SF-28 cell に 対する抗体）および細胞性免疫を調べた. その結果抗ウ イルス抗体（gp 51，p 24）は発病阻止にはあまり関与 しない事を明らかにした. しかし SF-28 に対する抗体 は発病直前から下降したり，あるいは検出しえなくなり 接種後43力月目に白血病で死亡した。乙れに対して, 臨 床的に正常な羊ではこの抗体は引き続き検出された。一 方, 正常羊および牛の NK 様細胞は BLV 持続感染細胞 に対して細胞障害活性を示したが，乙の活性は白血病動 物では有意に低下していた。また発病羊では，発病直前 よりこの活性は低下ないしは陰転した．乙れらの所見か 
ら SF-28 に対する抗体执よび NK 様細胞活性が発病阻 止に関連するあのと推測している.

II. ウイルスの側からの検討

BLV は onc gene をもたないがゆえに長い潜伏期を 要する可能性があるため分子レベルでの発病メカニズウ の解明を検討している．まず，BLV cDNA をプローブ として腫瘍細胞への組み込み方をサザン・ブロット法で 調べたところ，各個体別の腫瘍では組み込み位置は異な るが同一個体内の異なる腫瘍間では多くの場合組み込み 位置は同一であり腫瘍細胞の単クローン性が示唆された.
次に腫瘍 DNA を $\lambda$ (ラムダ) Charon $4 \mathrm{~A}$ ファージに 結合し E. coli を宿主として分子クローニングを行い， 1 ケのクローンをえた。 このクローンは $9 \mathrm{~kb}$ の BLV ゲノムを含み両端に反復配列 (LTR) を持っていた。他 の $\mathrm{BLV}$ 分離株の制限酵素地図亡比較すると $g a g, p o l$ 領域の塩基配列には著しい変化をみるが $e n v$ 領域はよ く保存されていた。この事から BLV 間での遺伝子変異 が示唆され, $3^{\prime}$ 側の保存されている領域と発癌の関係お よび細胞側 (発癌) 遺伝子との関連に興味がもたれる. 